\title{
The First FPS Indian Tour
}

\author{
By Sir Hugh Elliott
}

$\mathbf{T}$ $O$ the now comparatively teeming members of the Society who have experienced one of its African tours, it is hard to explain in a few words how India was so different and so very well worth while. For it was by no means a case of the mixture as before. But perhaps it would be better to try to convey the atmosphere in a tailpiece, and start with facts and figures.

A delayed start from London on February 18th meant that we arrived in Bombay only a few hours before departure time for the Gir Forest and its lions. It also meant that, not for the last time, Zafar Futehally, Secretary of the Bombay Natural History Society and co-leader for this part of the tour, had to come to our rescue with an alfresco breakfast conjured up miraculously by Mrs Futehally in their garden. After this we could scarcely be surprised by the behaviour of the Gir lions a couple of evenings later, which took not the slightest notice of whirring and clicking cameras 20 yards away.

Our next port of call, the Kanha National Park (to which, and for the rest of the tour, F. C. Daniel, Curator of the Bombay Natural History Museum, was our admirable co-leader) was so good that there was a risk of subsequent anti-climax. Here as nowhere else on the trip one could see within a short distance of the lodge numbers of animals, especially chital, barasingha and blackbuck and, with only a little extra trouble, tiger, gaur and several other species, not to mention a feast of birds. The extra trouble in the case of tiger merely meant climbing to the summit of an elephant or a watchtower, for the grass was long. Sad to relate, when a prima ballerina of a tigress suddenly emerged from the grass, and with a classic leap, put paid to a vulture which offended her, everyone was still fiddling with lenses and exposures.

The long journey from Kanha to Assam is chiefly memorable for the delightful supper party under the stars arranged for us at Calcutta by Mrs Anne Wright, a member of the Society. In Assam, the party split into two groups visiting in turn the Kaziranga and Manas sanctuaries. That this arrangement worked so smoothly was due to the expert and enthusiastic support of $\mathrm{Mr} \mathrm{E}$. P. Gee, who guided us at Kaziranga, secured permission for entry into the adjacent Bhutan sanctuary at Manas, and indeed had much to do with the successful planning of the tour as a whole. As a result it would be hard to say which was more enjoyable - Kaziranga with its buffaloes, barasingha, hog-deer, muntjac and frequent stately rhinos or Manas with its crystal-clear swift-flowing river, the banks alive with pratincoles and crossed at dawn and dusk by flights of pterodactyllike great Indian hornbills, while golden langur monkeys disported themselves on the fringing trees.

In the final phase of the tour the works of man and of nature were mixed in equal proportion: Delhi with its Red Fort and its fine zoo, where the Director, K. S. Sankhala, made us so welcome; Agra with the never- 
disappointing Taj Mahal, and the superb sanctuary of Keoladeo Ghana, where $\mathrm{HH}$ the Maharaja of Bharatpur most generously accommodated eighteen of us and entertained us all at his most hospitable table, and the Top Bird of the sanctuary, the lovely white Siberian crane, (reported as gone to its northern breeding grounds) appeared in a bevy of 70 from the sky and settled down to be photographed. Finally Jaipur, with its palaces and treasures, and the Sariska Wildlife Sanctuary in the tangled thorn-scrub hills of Alwar, where we were the first to use the newly-built rest-house, the best of its kind encountered on the tour, saw our first and only Chinkara gazelle and, later, some magnificent nilghai and sambhar stags by spotlight. Here too occurred the following 'atmospheric' incident:

\section{Tailpiece}

Time, 11.0 p.m. Place, a 30-foot ancient watchtower perched on a great rock in the woodlands above the cleft of a small river, across which, 50 yards away in a little clearing, the carcase of buffalo could just be distinguished as a black blob in the moonlight. But the five members of the party who had elected to spend the night on watch in the round tower-top chamber had not reckoned on it being carpeted inches deep in dunlopillo with the result that by 11.15 nothing could be heard but orchestrated snores. At 1.30 a.m., the tour leader woke with a start, and directed a powerful torch beam on the kill: it was only too clear that while they slept a tiger had enjoyed a very good meal, though now only a large mongoose was taking a snack. The co-leader gallantly offered to keep a real watch, but at 3.30 a.m., inadvertently swept a bottle of coca-cola on to the concrete floor, which produced a fair version of a bomb exploding and it was generally agreed that this would be anathema to tigers. About 3.45 p.m., the moon had gone when suddenly a sambhar started up its alarm signal like the beating of a gong. Everyone was lined up at the window. The minutes seemed long ones and the sambhar's call died away. Ready. The spotlight stabbed the dark and there he stood, a magnificent male glaring green-eyed. When dawn came the tiger had gone and the vultures swept down like rockets; the pug-marks were measured - about six inches. It was left to the lady of the party to produce the appropriate quotation 'Tiger, tiger, burning bright in the forests of the night ....'

\section{Orang-utans in Sabah}

Mrs Barbara Harrisson writes: the semi-wild female orang-utan who mated with a wild male orang-utan at Sepilok Forest Reserve near Sandakan, Sabah, and gave birth to a baby is not one of the two animals cared for by me in Sarawak's Bako Park between 1962-65 as reported in ORYX, December 1967, page 187. The Sepilok Orang-utan Project is entirely financed by the State of Sabah and run by its Game Warden since inception in 1964. The animals cared for in Sarawak between 1962-65 were transferred to Sepilok in April 1965 when the Sarawak project was discontinued. There are at present 18 young orphaned orang-utans cared for at Sepilok. They are given complete freedom within the protected forest there which also incorporates a population of wild orang-utans. The female who gave birth last year is the first of the orang-utans on the Sepilok project to reach maturity. 